\title{
Skill-based Categories: An Alternative of Language Learning Strategy Measurement
}

\author{
Ag. Bambang Setiyadi \\ Faculty of Education, Lampung University, Lampung Province, Indonesia
}

\begin{abstract}
Many studies have been conducted to identify and classify language learning strategies (Rubin, 1975; Naiman et al, 1978; Fillmore, 1979; O'Malley et al, 1985 and 1990; Politzer and Groarty, 1985; Prokop, 1989; Oxford, 1990b; and Wenden, 1991a). Different studies have used different classifications and different ways of measuring learning strategies. This study attempted to explore what language learning strategies employed by students at EFL setting and to propose an alternative of learning strategy measurement for learners who study English as a foreign language. In the current study a total of 88 enrolled at English Department participated. After a series of reliability and correlation analysis the current study proposes an alternative of language learning strategy measurement. The learning strategy measurement in this study consists cognitive, metacognitive and social strategies which are grouped under skill-based categories: listening category, listening category, reading category and writing category.
\end{abstract}

Index Terms - learning strategy, strategy classification, learning strategy measurement, learning strategy in EFL context, skill-based strategy

\section{INTRODUCTION}

It seems obvious that there is no second language learning acquisition without learning strategies, either conscious or unconscious. This is the area to which the research conducted by Rubin (1975), Naiman et al. (1978), Fillmore (1979), Politzer and McGroarty (1985), O'Malley and Chamot (1990), Oxford and Nyikos (1989) and Wenden (1991b) has been devoted. They have elaborated on language learning strategies and suggested different ways of classifying language learning strategies. Some studies on language learning strategies have shown that the learning strategies contributed to the success in learning English. A study suggesting that learning strategies affect language achievement was conducted by Bialystok and Frohlich (1978). Their study, which explored variables of classroom achievement in second language learning, showed that many factors were correlated with language achievement, but only two of them: aptitude and strategy use were significant in predicting performance. Another study by Dreyer and Oxford (1999, p.73) also provides evidence on a significant relationship between strategy use and ESL proficiency. The studies have proved that the use of learning strategies discriminates between successful and unsuccessful learners.

Learning strategies, which are defined as steps or actions taken by language learners to enhance any aspect of their learning (Oxford 1990a, p. 70), seem to be more than a reflection of learning style. It seems difficult to categorize whether certain learning strategies of an individual are originally his/her own, or developed and adapted from certain external factors. Oxford's definition implies that learning strategies are conscious activities because students are learning a language while they are conscious of the process. However, not all writers agree with a concept that learning always takes place while subjects are conscious or aware of this. Some researchers have argued over the consciousunconscious distinction (McLaughlin, 1990, Krashen, 1979). Kihlstrom (1996, p. 33) states that subjects may be simply unaware of some stimulus response, or of what they are learning; subjects can engage in learning when they are not conscious at all, for example when they are asleep or anaesthetized. Referring to Oxford's definition (1990a), in this study, learning strategies refer to conscious activities since students seem to be aware what actions or steps they are taking to enhance their learning process to acquire another language. Or, at very least the students initiate the use of those strategies purposively and they may later be said to have become an automatic part of the students' repertoire of behavior for learning. This concept of learning strategies is also commonly used by many researchers, providing a framework for their predefined questionnaires of language learning strategies (Oxford and Nyikos, 1989; and Awang Hasyim and Syed Sahil, 1994; Green and Oxford, 1995; Park, 1997; and Kaylani, 1999).

Different researchers have proposed different ways of classifying learning strategies and different ways of measuring the strategies. One of the most commonly used measurements was the Strategy Inventory for Language Learning (SILL), which has been introduced by Oxford. This measurement has been used around the world (Awang Hasyim and Syed Sahil, 1994, Oxford, 1996, Vahid Baghban, 2012, and Nosidlak, 2013). However, Park (1997), who conducted a research on the English learning strategies used by Korean students, provides an argument that not all strategies the students used in learning English were inventoried in Oxford's SILL (p.217). That the SILL might be inadequate in accurately reporting strategy use was also suspected by Grainger (1997, p.383), who explored the relationship between strategy use and ethnicity of learners of Japanese. He suspects the inadequacy of the SILL since he found that in 
learning Japanese the students of Asian backgrounds do not follow traditional patterns of strategy use as identified in other major studies of language learning strategies.

Learners from different cultures seem to learn a foreign language in different ways; learners who live in a society where the target language is spoken as a foreign language, like Asian students, may use different learning strategies; therefore, we need a measurement of learning strategies that provide them with enough choices of strategies employed in their learning. This study is aimed at developing a measurement of learning strategies of tertiary EFL students.

\section{Methodology}

The participants of this study were 88 English Department students who had been enrolled for 6 semesters at the Faculty of Education of the University of Lampung, Indonesia. The reason for selecting such a sample was that all subjects were studying English in an EFL tertiary setting.

To collect data about language learning strategies, a questionnaire has been developed in a predefined questionnaire of language learning strategies and it is measured in a Likert-scale. The classification of the language learning strategies in the questionnaire was based on theory driving decision making and theories of skill-based learning strategies. These strategies cover four areas of the language skills: speaking, listening, reading and writing and each area consists of 20 items (see Appendix A). In each category, the language learning strategies were classified into cognitive processes, metacognitive processes, and social processes (see Appendix B).

In this study the items were grouped into one single scale that was called Language Learning Strategy Classification (LLSQ). Some items of the LLSQ have been taken from the previous researchers (Rubin, 1975; Fillmore, 1979; Naiman et al., 1978; Politzer and McGroarty, 1985; and Oxford and Nyikos, 1989) and some others have been newly developed based on interviews with English learners and teachers (for detail information, see Setiyadi, 1999). Inspired by the SILL of Oxford, the questionnaire measures learning strategies employed by English learners by providing choices ranging from "never " to "always" and the scores range from 1 to 5.

To increase the internal consistency of the hypothesized scales, Cronbach Alpha coefficients of internal consistency were computed for the scales of skill-based areas, namely: speaking, listening, reading and writing, and then continued to measure how the items of the LLSQ measure the same construct, namely learning strategies of students in EFL tertiary setting. An effort was also made to inspect correlation matrix to see if justified to consider the concept of the four skill areas of English included in the LLSQ.

\section{RESULT AND DISCUSSION}

This research has been initiated with students taking a three-month English course at Language Centre, numbering 79 participants (Setiyadi, 2001 and 2004). The study showed that the Cronbach alphas of sub-scales of the LLSQ were .73, 67, 69 and 80 for speaking, listening, reading and writing respectively (Setiyadi, 2004). The Cronbach's alpha of the strategies were not high and the intercorrelation among the strategies developed in the LLSQ was not measured in the study. This recent research was conducted with English Department students who had learned English for six semesters in EFL context. The participants were assumed to have enough exposure to English learning. Compared to the original study, the recent research shows that the Cronbach alphas of the recent research are higher: the alphas of the strategies are 75, 71, 77 and 72 for listening, speaking, reading and writing respectively. The finding of this research also shows that all items of the LLSQ are highly correlated with the Cronbach's alpha is 0.88 .

To measure the reliability of the strategies of listening, reliability analysis was run. The criteria on reliability of internal consistency with the Cronbach's alpha 0.75 were met in this analysis (see Table 1). The strategies of this category were justified to be grouped into one single scale that was called listening strategies. The listening category of the LLSQ has 20 learning strategies (see Table 2).

TABLE 1:

THE CRONBACH ALPHA OF LISTENING STRATEGIES

\begin{tabular}{|l|l|l|}
\hline Cronbach's Alpha & $\begin{array}{l}\text { Cronbach's Alpha Based on } \\
\text { Standardized Items }\end{array}$ & N of Items \\
\hline .753 & .750 & 20 \\
\hline
\end{tabular}


TABLE 2:

ITEM-TOTAL STATISTICS

\begin{tabular}{|c|c|c|c|c|c|}
\hline & $\begin{array}{l}\text { Scale Mean if Item } \\
\text { Deleted }\end{array}$ & $\begin{array}{l}\text { Scale Variance if } \\
\text { Item Deleted }\end{array}$ & $\begin{array}{l}\text { Corrected Item-Total } \\
\text { Correlation }\end{array}$ & $\begin{array}{l}\text { Squared Multiple } \\
\text { Correlation }\end{array}$ & $\begin{array}{l}\text { Cronbach's Alpha if Item } \\
\text { Deleted }\end{array}$ \\
\hline L1 & 63.1932 & 63.422 & .213 & .222 & .750 \\
\hline L2 & 62.5227 & 63.816 & .197 & .491 & .751 \\
\hline L3 & 62.0114 & 64.471 & .170 & .509 & .752 \\
\hline L4 & 62.5341 & 63.999 & .167 & .270 & .753 \\
\hline L5 & 64.3295 & 61.304 & .275 & .418 & .746 \\
\hline L6 & 64.0114 & 62.678 & .239 & .393 & .748 \\
\hline L7 & 63.5341 & 63.286 & .207 & .414 & .751 \\
\hline L8 & 62.7273 & 60.568 & .387 & .356 & .737 \\
\hline L9 & 62.4545 & 63.009 & .221 & .361 & .750 \\
\hline L10 & 62.5909 & 60.819 & .353 & .355 & .740 \\
\hline L11 & 63.3068 & 64.008 & .189 & .315 & .751 \\
\hline L12 & 63.3182 & 59.277 & .390 & .461 & .736 \\
\hline L13 & 63.5795 & 58.798 & .378 & .409 & .737 \\
\hline L14 & 63.3523 & 60.829 & .326 & .372 & .742 \\
\hline L15 & 62.7841 & 58.010 & .523 & .567 & .726 \\
\hline L16 & 62.5682 & 57.880 & .565 & .675 & .723 \\
\hline L17 & 62.7386 & 60.655 & .369 & .429 & .739 \\
\hline L18 & 62.1023 & 61.633 & .322 & .403 & .742 \\
\hline L19 & 62.3068 & 61.043 & .459 & .466 & .734 \\
\hline L20 & 62.7841 & 62.217 & .307 & .356 & .743 \\
\hline
\end{tabular}

The Cronbach's alpha for the 20 items of speaking category was 0.52 (see Table 3). Since the criteria on reliability of internal consistency were not met, speaking strategy no. 1 was evaluated and justified to be dropped from the scale (see Table 4) and the speaking category has 19 strategies with the Cronbach's alpha 0.71 (see Table 5) and the speaking category of the measurement has 19 learning strategies (see Table 6).

TABLE 3:

THE CRONBACH ALPHA OF SPEAKING STRATEGIES WITH 20 ITEMS

\begin{tabular}{|l|l|l|}
\hline Cronbach's Alpha & $\begin{array}{l}\text { Cronbach's Alpha Based on } \\
\text { Standardized Items }\end{array}$ & N of Items \\
\hline .528 & .698 & 20 \\
\hline
\end{tabular}


TABLE 4:

ITEM-TOTAL STATISTICS

\begin{tabular}{|c|c|c|c|c|c|}
\hline & $\begin{array}{l}\text { Scale Mean if Item } \\
\text { Deleted }\end{array}$ & $\begin{array}{l}\text { Scale Variance if } \\
\text { Item Deleted }\end{array}$ & $\begin{array}{l}\text { Corrected Item-Total } \\
\text { Correlation }\end{array}$ & $\begin{array}{l}\text { Squared Multiple } \\
\text { Correlation }\end{array}$ & $\begin{array}{l}\text { Cronbach's Alpha if Item } \\
\text { Deleted }\end{array}$ \\
\hline S1 & 62.7159 & 58.757 & -.015 & .190 & .717 \\
\hline $\mathrm{S} 2$ & 62.0341 & 77.298 & -.035 & .248 & .539 \\
\hline S3 & 61.9432 & 72.307 & .257 & .447 & .506 \\
\hline S4 & 62.8636 & 72.855 & .260 & .403 & .507 \\
\hline S5 & 62.5000 & 72.667 & .226 & .459 & .509 \\
\hline S6 & 62.4432 & 73.330 & .168 & .312 & .516 \\
\hline S7 & 64.2159 & 75.413 & .131 & .233 & .522 \\
\hline S8 & 61.8409 & 73.147 & .180 & .255 & .515 \\
\hline S9 & 62.4091 & 74.796 & .110 & .428 & .524 \\
\hline S10 & 62.8295 & 70.005 & .336 & .415 & .492 \\
\hline S11 & 62.0114 & 69.988 & .381 & .470 & .489 \\
\hline $\mathrm{S} 12$ & 61.9545 & 71.377 & .376 & .509 & .495 \\
\hline S13 & 62.2955 & 67.544 & .527 & .514 & .469 \\
\hline S14 & 62.0455 & 71.745 & .304 & .343 & .501 \\
\hline S15 & 62.3864 & 67.918 & .431 & .468 & .477 \\
\hline S16 & 62.5682 & 72.524 & .189 & .473 & .513 \\
\hline S17 & 62.2955 & 72.096 & .250 & .505 & .506 \\
\hline S18 & 64.0000 & 75.563 & .042 & .430 & .533 \\
\hline S19 & 62.7727 & 74.844 & .148 & .373 & .520 \\
\hline S20 & 62.2045 & 69.682 & .356 & .365 & .489 \\
\hline
\end{tabular}

TABLE 5:

THE CRONBACH ALPHA OF SPEAKING STRATGIES WITH 19 ITEMS

\begin{tabular}{|l|l|l|}
\hline Cronbach's Alpha & $\begin{array}{l}\text { Cronbach's Alpha Based on } \\
\text { Standardized Items }\end{array}$ & N of Items \\
\hline .717 & .714 & 19 \\
\hline
\end{tabular}

TABLE 6:

ITEM-TOTAL STATISTICS

\begin{tabular}{|c|c|c|c|c|c|}
\hline & $\begin{array}{l}\text { Scale Mean if Item } \\
\text { Deleted }\end{array}$ & $\begin{array}{l}\text { Scale Variance if } \\
\text { Item Deleted }\end{array}$ & \begin{tabular}{|l|} 
Corrected Item-Total \\
Correlation
\end{tabular} & $\begin{array}{l}\text { Squared Multiple } \\
\text { Correlation }\end{array}$ & $\begin{array}{l}\text { Cronbach's Alpha if Item } \\
\text { Deleted }\end{array}$ \\
\hline $\mathrm{S} 2$ & 58.9432 & 58.077 & -.005 & .248 & .729 \\
\hline S3 & 58.8523 & 53.116 & .331 & .447 & .703 \\
\hline $\mathrm{S} 4$ & 59.7727 & 54.224 & .292 & .402 & .706 \\
\hline S5 & 59.4091 & 54.176 & .244 & .458 & .710 \\
\hline S6 & 59.3523 & 54.254 & .215 & .312 & .714 \\
\hline S7 & 61.1250 & 56.364 & .179 & .219 & .715 \\
\hline S8 & 58.7500 & 55.017 & .168 & .235 & .718 \\
\hline S9 & 59.3182 & 54.633 & .228 & .389 & .712 \\
\hline $\mathrm{S} 10$ & 59.7386 & 52.908 & .284 & .372 & .707 \\
\hline S11 & 58.9205 & 50.304 & .513 & .467 & .685 \\
\hline $\mathrm{S} 12$ & 58.8636 & 52.924 & .412 & .509 & .697 \\
\hline S13 & 59.2045 & 49.084 & .598 & .505 & .676 \\
\hline S14 & 58.9545 & 52.343 & .403 & .336 & .696 \\
\hline S15 & 59.2955 & 49.544 & .481 & .464 & .685 \\
\hline S16 & 59.4773 & 52.873 & .275 & .435 & .708 \\
\hline S17 & 59.2045 & 53.084 & .308 & .500 & .705 \\
\hline S18 & 60.9091 & 57.417 & .010 & .418 & .733 \\
\hline S19 & 59.6818 & 56.082 & .172 & .366 & .715 \\
\hline $\mathrm{S} 20$ & 59.1136 & 51.274 & .394 & .360 & .696 \\
\hline
\end{tabular}

The criteria on reliability of internal consistency for the reading strategies were met in this analysis. The strategies were justified to be grouped into one single scale that was called reading strategies. The reading category has 20 learning strategies with the Cronbach's alpha 0.77 (see Table 6 and 7). 
TABLE 6:

THE CRONBACH ALPHA OF READING STRATEGIES

\begin{tabular}{|l|l|l|}
\hline \multicolumn{2}{|c|}{ THE CRONBACH ALPHA OF READING STRATEGIES } \\
\hline Cronbach's Alpha & $\begin{array}{l}\text { Cronbach's Alpha Based on } \\
\text { Standardized Items }\end{array}$ & N of Items \\
\hline .770 & .771 & 20 \\
\hline
\end{tabular}

TABLE 7:

ITEM-TOTAL STATISTICS

\begin{tabular}{|c|c|c|c|c|c|}
\hline & $\begin{array}{l}\text { Scale Mean if Item } \\
\text { Deleted }\end{array}$ & $\begin{array}{l}\text { Scale Variance if Item } \\
\text { Deleted }\end{array}$ & $\begin{array}{l}\text { Corrected Item-Total } \\
\text { Correlation }\end{array}$ & $\begin{array}{l}\text { Squared Multiple } \\
\text { Correlation }\end{array}$ & $\begin{array}{l}\text { Cronbach's Alpha if } \\
\text { Item Deleted }\end{array}$ \\
\hline $\mathrm{R} 1$ & 62.6136 & 62.194 & .196 & .327 & .770 \\
\hline $\mathrm{R} 2$ & 62.8295 & 62.764 & .197 & .240 & .769 \\
\hline R3 & 63.4659 & 57.884 & .405 & .320 & .756 \\
\hline R4 & 63.0114 & 61.804 & .251 & .308 & .766 \\
\hline R5 & 63.1591 & 60.434 & .267 & .253 & .766 \\
\hline R6 & 62.5682 & 60.363 & .410 & .419 & .757 \\
\hline R7 & 62.5455 & 62.963 & .165 & .317 & .771 \\
\hline R8 & 63.7045 & 62.739 & .130 & .257 & .775 \\
\hline R9 & 63.2841 & 56.872 & .441 & .368 & .752 \\
\hline R10 & 63.4886 & 58.575 & .481 & .437 & .752 \\
\hline R11 & 63.0341 & 58.700 & .437 & .520 & .754 \\
\hline R12 & 62.7955 & 60.647 & .334 & .364 & .761 \\
\hline R13 & 63.2159 & 58.079 & .420 & .355 & .754 \\
\hline R14 & 63.1023 & 54.966 & .627 & .569 & .738 \\
\hline R15 & 62.9091 & 57.716 & .507 & .416 & .749 \\
\hline R16 & 63.2841 & 61.010 & .332 & .302 & .761 \\
\hline R17 & 63.1023 & 62.920 & .128 & .139 & .775 \\
\hline R18 & 63.1591 & 58.871 & .415 & .508 & .755 \\
\hline R19 & 62.6136 & 60.723 & .282 & .407 & .764 \\
\hline R20 & 64.3182 & 59.507 & .237 & .292 & .771 \\
\hline
\end{tabular}

The criteria on reliability of internal consistency of the learning strategies of writing skill were met so that the strategies under the writing category introduced in the LLSQ were justified to be grouped into one single scale that was called writing strategies. The Cronbach's alpha of the writing strategies was 0.71 (see Table 8) and the writing category of the LLSQ has 20 strategies (see Table 9).

TABLE 8:

THE CRONBACH ALPHA OF WRITING STRATEGIES

\begin{tabular}{|l|l|l|}
\hline Cronbach's Alpha & $\begin{array}{l}\text { Cronbach's Alpha Based on } \\
\text { Standardized Items }\end{array}$ & N of Items \\
\hline .718 & .728 & 20 \\
\hline
\end{tabular}


TABLE 9:

ITEM-TOTAL STATISTICS

\begin{tabular}{|c|c|c|c|c|c|}
\hline & $\begin{array}{l}\text { Scale Mean if Item } \\
\text { Deleted }\end{array}$ & $\begin{array}{l}\text { Scale Variance if } \\
\text { Item Deleted }\end{array}$ & \begin{tabular}{|l|} 
Corrected Item-Total \\
Correlation
\end{tabular} & $\begin{array}{l}\text { Squared Multiple } \\
\text { Correlation }\end{array}$ & $\begin{array}{l}\text { Cronbach's Alpha if Item } \\
\text { Deleted }\end{array}$ \\
\hline W1 & 60.3636 & 54.280 & .220 & .392 & .713 \\
\hline W2 & 60.5114 & 52.437 & .335 & .459 & .702 \\
\hline W3 & 61.9545 & 51.354 & .291 & .304 & .708 \\
\hline W4 & 60.9886 & 52.379 & .381 & .328 & .699 \\
\hline W5 & 61.0000 & 54.529 & .314 & .340 & .706 \\
\hline W6 & 61.0455 & 52.067 & .422 & .513 & .696 \\
\hline W7 & 61.9659 & 53.275 & .279 & .588 & .708 \\
\hline W8 & 60.6932 & 57.479 & .013 & .337 & .728 \\
\hline W9 & 61.4773 & 52.942 & .245 & .563 & .712 \\
\hline W10 & 61.8409 & 53.882 & .252 & .300 & .710 \\
\hline W11 & 60.1023 & 54.116 & .300 & .340 & .706 \\
\hline W12 & 61.5909 & 53.118 & .333 & .455 & .703 \\
\hline W13 & 60.4091 & 52.888 & .470 & .524 & .695 \\
\hline W14 & 60.9205 & 54.948 & .243 & .454 & .711 \\
\hline W15 & 61.0341 & 53.413 & .340 & .376 & .703 \\
\hline W16 & 60.3750 & 54.329 & .223 & .530 & .713 \\
\hline W17 & 60.6591 & 52.871 & .374 & .449 & .700 \\
\hline W18 & 61.1364 & 55.315 & .139 & .359 & .720 \\
\hline W19 & 62.3409 & 52.434 & .267 & .396 & .710 \\
\hline W20 & 60.7727 & 51.856 & .350 & .384 & .701 \\
\hline
\end{tabular}

The criteria on reliability of internal consistency for the 80 items were actually high in this analysis (see Table 10) but, referring to one dropped item from the speaking category, the internal consistency was measured only for 79 items so that the strategies in this measurement were justified to be grouped into one single scale that was called Language Learning Strategy Classification or the LLSQ and the Cronbach's alpha of the items was 0.90 (see Table 11).

TABLE 10:

THE CRONBACH ALPHA OF ALL ITEMS (BEFORE 1 ITEM OF SPEAKING STRATEGIES DROPPED
\begin{tabular}{|l|l|l|}
\hline Cronbach's Alpha & $\begin{array}{l}\text { Cronbach's Alpha Based on } \\
\text { Standardized Items }\end{array}$ & N of Items \\
\hline .881 & .904 & 80 \\
\hline
\end{tabular}

TABLE 11:

THE CRONBACH ALPHA OF ALL ITEMS (AFTER 1 ITEM OF SPEAKING STRATEGIES DROPPED)

\begin{tabular}{|l|l|l|}
\hline Cronbach's Alpha & $\begin{array}{l}\text { Cronbach's Alpha Based on } \\
\text { Standardized Items }\end{array}$ & N of Items \\
\hline .905 & .905 & 79 \\
\hline
\end{tabular}

Since the classification of the language learning strategies in the recent study was based on theory driving decision, correlation analysis was run to consider the concept of the four skill areas of English. As shown in Table 12, the four skill-based categories of the strategies are positively and significantly correlated. The relatively high levels of Cronbach's alpha showed that the scales were internally consistent. 
TABLE 12:

CORRELATIONS AMONG THE FOUR SKILL STRATEGIES

\begin{tabular}{|c|c|c|c|c|c|}
\hline & & $\begin{array}{l}\text { mean of speaking } \\
\text { strategy }\end{array}$ & $\begin{array}{l}\text { mean of listening } \\
\text { strategy }\end{array}$ & $\begin{array}{l}\text { mean of reading } \\
\text { strategy }\end{array}$ & $\begin{array}{l}\text { mean of } \\
\text { Writing strategy }\end{array}$ \\
\hline \multirow[t]{3}{*}{ mean of speaking strategy } & $\begin{array}{l}\text { Pearson } \\
\text { Correlation }\end{array}$ & 1 & $.528^{* *}$ & $.521^{* *}$ & $.445^{* *}$ \\
\hline & Sig. (2-tailed) & & .000 & .000 & .000 \\
\hline & $\mathrm{N}$ & 88 & 88 & 88 & 88 \\
\hline \multirow[t]{3}{*}{ mean of listening strategy } & $\begin{array}{l}\text { Pearson } \\
\text { Correlation }\end{array}$ & $.528^{* *}$ & 1 & & $.481^{* *}$ \\
\hline & Sig. (2-tailed) & .000 & & .000 & .000 \\
\hline & $\mathrm{N}$ & 88 & 88 & 88 & 88 \\
\hline \multirow[t]{3}{*}{ mean of reading strategy } & $\begin{array}{l}\text { Pearson } \\
\text { Correlation }\end{array}$ & $.521^{* *}$ & & 1 & \\
\hline & Sig. (2-tailed) & .000 & .000 & & .000 \\
\hline & $\mathrm{N}$ & 88 & 88 & 88 & 88 \\
\hline \multirow[t]{3}{*}{ mean of Writing strategy } & $\begin{array}{l}\text { Pearson } \\
\text { Correlation }\end{array}$ & $445^{* *}$ & $.481^{* *}$ & & 1 \\
\hline & Sig. (2-tailed) & .000 & .000 & .000 & \\
\hline & $\mathrm{N}$ & 88 & 88 & 88 & 88 \\
\hline
\end{tabular}

**. Correlation is significant at the 0.01 level (2-tailed).

\section{CONCLUSION AND SUGGESTION}

After a series of reliability, the items under the skill-based categories were assumed to belong to the hypothesized scales. Language learning strategies grouped under listening category, reading category and writing category consist of 20 items and speaking category consists of 19 items. Speaking strategy no.1, namely I use rhymes to remember new English words. was dropped since the item was not very correlated with the other strategies grouped under the speaking category. In total, the measurement has 79 language learning strategies even though, considering the high magnitude of Crobach's alpha of the 80 item reliability. To measure the use of learning strategies, we may use 80 language learning strategies introduced in the LLSQ. The classification of the strategies suggested in this study is probably not final and the dropped strategy from the speaking category may be evaluated. There may also be overlap between the strategies classified under different categories. It needs to be confirmed with other future studies on language learning strategies.

The intercorrelations among the categories mean that increased frequency of strategy use under one skill-based category is associated with an increase in the use of those of the other categories. This is interesting because originally the strategies were developed in different areas of the language skills: speaking, listening, reading, and writing. The findings in this study, supported by Purpura (1997) and Wenden (1991b), may be interpreted as a sign of mutual conceptual dependence among strategies that language learners use in learning the target language. This is probably understood as evidence that, in learning a foreign language, they do not rely on a single category or certain groups of strategies only, but they employ many strategies. This calls for further studies to determine whether the use of strategy combination in a certain way plays an important role in the successful learning of a foreign language and, if so, how the strategies are effectively combined. Further research also needs to explore how differently successful learners learn a foreign language from less successful ones.

\section{APPEndix A. LANGUAGE LeARning STRATEgy Questionnaire (LLSQ)}

Directions

You will find some statements about learning English. On the separate worksheet, write the response (1, 2, 3, 4, or 5) that tells HOW TRUE OF YOU THE STATEMENT IS.

1. Never or almost never true of me

2. Usually not true of me

3. Somewhat true of me

4. Usually true of me

5. Always or almost always true of me

In Listening

1. I try to guess what somebody is saying by using grammatical rules.

2. I learn English by watching English TV programs.

3. I learn English by listening to English songs or other listening scripts.

4. I try to understand what somebody is saying by translating into Indonesian.

5. I draw an image or picture of the word in order to remember the word. 
6. I connect the pronunciation of the word with the Indonesian word which has a similar sound.

7. I concentrate on the grammar rather than on the communication.

8. I try to understand the idea by referring to previous experiences I have had.

9. I try to guess by using a word (s) that is familiar to me.

10. In Listening, I take notes to remember ideas.

11. I try to understand every individual word to understand the passage

12. I listen to what I say to practice my listening skill.

13. Before practicing my listening skill, I prepare a topic, pronunciation or grammatical rules which give me the greatest trouble.

14. I try to remember a sentence(s) spoken face-to-face or on cassettes and analyze them by myself.

15. After a listening practice, I check and recheck my understanding.

16. I correct the mistakes that I produce orally.

17. I try to be aware of which sounds give the greatest trouble. In this way I can pay special attention to them while I listen and practice.

18. If I cannot understand what somebody is saying, I ask him/her to slow down or say it again.

19. 19. Listening to what somebody is saying improves my listening skill.

20. 20. In a group discussion, my listening skill is improved.

\section{In Speaking}

1. I use rhymes to remember new English words.

2. I try to remember new English words by pronouncing them.

3. I speak a word or a sentence several times to remember it.

4. I try to learn a new pattern by making a sentence orally.

5. I try to translate Indonesian sentences into English sentences and produce them orally.

6. I try to remember what the English word equivalent to Indonesian word is.

7. I tape record the sentences I produce.

8. I mix Indonesian words and English words if I do not know the English words.

9. I put words into rules that I know in speaking.

10. Before I respond orally to questions, I write out the answers.

11. I try to correct my mistakes that I produce orally.

12. I try to speak with myself to improve my speaking.

13. I try to evaluate my utterances after speaking.

14. I notice my English mistakes, and use that information to help me do better.

15. I prepare a topic or grammatical rules in speaking practice.

16. I ask somebody to correct me when I talk.

17. I practice speaking with my friends or my teachers.

18. I practice English with native speakers.

19. I ask questions in English.

20. If I cannot think during a conversation in English, I use gestures.

\section{In Reading}

1. To understand unfamiliar English words while I am reading, I guess from available clues.

2. I learn English by reading English books or magazines.

3. I connect the spellings of English words with similar Indonesian words to understand the meanings.

4. I try to understand sentences by analysing their patterns.

5. I try to translate word for word.

6. I try to understand the passage by using my general knowledge and experience.

7. I use the key words to understand the whole ideas.

8. I read the passage aloud.

9. I take notes to remember the ideas.

10. While I read a text, I try to anticipate the story line.

11. I read a text more for ideas than words.

12. I correct my mistakes by rereading the text.

13. I choose a topic or certain materials for my practice.

14. I check and recheck my understanding after reading a passage.

15. If I cannot understand a reading passage, I try to analyse what difficulty I actually have.

16. In reading, I pick out key words and repeat them to myself.

17. I try to be aware of which words or grammar rules give me the greatest trouble. In this way I can pay special attention to them while I read and practice.

18. I discuss reading passages with my friends.

19. If I do not understand the content of a reading passage, I ask my friends or my teachers for help.

20. I improve my reading skill by reading letters from my friends. 


\section{In Writing}

1. If I do not know how to express my ideas in English while writing, I keep writing using certain rules that I know.

2. I write what I am thinking about.

3. I keep a diary.

4. I try to remember the meanings of words or the patterns by writing them

5. I write sentences to apply certain rules.

6. I try to translate word for word.

7. I mix Indonesian words and English words in writing.

8. I write the main ideas first as a guideline.

9. I use Indonesian words if I do not know the English words.

10. I use Indonesian patterns to keep writing in English.

11. I consult a dictionary to find out the meanings of words.

12. I write out new material over and over.

13. I try to memorize the meanings of words.

14. I rewrite my composition by correcting the mistakes that I notice.

15. I choose a topic to improve my writing skill.

16. I read my writing and correct the mistakes.

17. I try to be aware of which words or grammar rules give the greatest trouble, this way I can pay special attention to them while I write and practice.

18. I write a message to my friends in English for practice.

19. I write letters in English to my friends.

20. I ask my friends or my teachers to correct my writing.

\section{Worksheet}

\begin{tabular}{|c|c|c|c|c|}
\hline \multicolumn{5}{|c|}{ Name: } \\
\hline IN LISTENING & IN SPEAKING & IN READING & \multicolumn{2}{|c|}{ IN WRITING } \\
\hline 1 & 1 & 1 & 1 & \\
\hline 2 & 2 & 2 & 2 & \\
\hline 3 & 3 & 3 & 3 & \\
\hline 4 & 4 & 4 & 4 & \\
\hline 5 & 5 & 5 & 5 & \\
\hline 6 & 6 & 6 & 6 & \\
\hline 7 & 7 & 7 & 7 & \\
\hline 8 & 8 & 8 & 8 & \\
\hline 9 & 9 & 9 & 9 & \\
\hline 10 & 10 & 10 & 10 & \\
\hline 11 & 11 & 11 & 11 & \\
\hline 12 & 12 & 12 & 12 & \\
\hline 13 & 13 & 13 & 13 & \\
\hline 14 & 14 & 14 & 14 & \\
\hline 15 & 15 & 15 & 15 & \\
\hline 16 & 16 & 16 & 16 & \\
\hline 17 & 17 & 17 & 17 & \\
\hline 18 & 18 & 18 & 18 & \\
\hline 19 & 19 & 19 & 19 & \\
\hline 20 & 20 & 20 & 20 & \\
\hline
\end{tabular}

APPENDIX B, CATEGORIES OF SKILL-BASEd STRATEGIES

\begin{tabular}{|l|l|l|l|l|}
\hline & Speaking & Listening & Reading & Writing \\
\hline $\begin{array}{l}\text { Cognitive } \\
\text { Strategies }\end{array}$ & Item nos 1-10 & Item nos 1-11 & Item nos 1-11 & Item nos 1-13 \\
\hline $\begin{array}{l}\text { Metacognitive } \\
\text { Strategies }\end{array}$ & Item nos 11-15 & Item nos12-17 & Item nos 12-17 & Item nos14-17 \\
\hline $\begin{array}{l}\text { Social } \\
\text { Strategies }\end{array}$ & Item nos 16-20 & Item nos 18-20 & Item nos 18-20 & Item nos 18-20 \\
\hline
\end{tabular}

\section{ACKNOWLEDGMENT}

The author wishes to thank Prof. Dr. Patuan Raja, Meila Sari and Desi Fitri. This work was supported in part by a grant from the Faculty of Education of Lampung University. 


\section{REFERENCES}

[1] Awang Hashim, Rosna and Syed Sahil, Sharifah. (1994). Examining learners' language learning strategies. Singapore: RELC Journal, Vol.25 No.2, 1-20.

[2] Bialystok, Ellen and Frohlich, Maria. (1978). Variables of classroom achievement in second language learning. Modern Language Journal, Vol. LXII, No. 7, 327-335.

[3] Dreyer, Carisma and Oxford, Rebecaa L. (1996). Learning strategies and other predictors of ESL proficiency among Afrikaans speakers in South Africa. In Rebecca L. Oxford (Ed.), Language learning strategies in the world, pp. 61-74. Honolulu: University of Hawaii.

[4] Fillmore, Lily Wong. (1979). Individual differences in second language acquisition. In Charles J. Fillmore, at al. (Eds.), Individual differences in language ability and language behavior, pp. 203-228. New York: Academic Press.

[5] Grainger, Peter Ralph. (1997). Language learning strategies for learners of Japanese: investigating ethnicity. Foreign Language Annals, 30, No.3, 378-385.

[6] Green John M. and Oxford, Rebecca. (1995). A closer look at learning strategies, L2 proficiency, and gender. TESOL Quarterly, 29 No 2, 261-297.

[7] Kaylani, Cora. (1996). The influence of gender and motivation on EFL learning strategy use in Jordan. In Rebecca L. Oxford (Ed), Language learning strategies around the world, pp.75-88. Honolulu: University of Hawaii.

[8] Kihlstrom, John F. (1996). Perception without awareness of what is perceived, learning without awareness of what is learned. In Max Velman (Ed.), The science of consciousness. pp. 23-46. London and New York: Routledge.

[9] Krashen, Stephen D. (1979). A response to McLaughlin, "the monitor model: some methodological considerations". Language Learning, 29, pp. 151-167.

[10] McLaughlin, Barry. (1990). Conscious and unconscious learning. TESOL Quarterly, Vol.24, pp. 617-634.

[11] Naiman, N, Frochlich, M, Steren, H.H., Todesco, A. (1978). The good language learner. Ontario: The Ontario

[12] Nosidlak,Katarzyna Maria. (2013). Vocabulary learning strategies of the advanced students. Journal of Language Teaching and Research, Vol. 4, No. 4, pp. 655-661, July 2013.

[13] O’Malley, Michael J. \& Chamot, A. U. (1990). Learning strategies in second language acquisition. Cambridge-London: Cambridge University Press.

[14] O’Malley, Michael J et al. (1985). Learning strategies used by beginning and intermediate ESL students. Language Learning, Vol.35, No.1. pp. 21-44.

[15] Oxford, Rebecca. (1990a). Styles, strategies, and aptitude. In Thomas S. Parry.\& Charles W Stansfield (Eds.), Language aptitude reconsidered, pp. 67-119. New Jersey: Prentice Hall Regents.

[16] Oxford, Rebecca. (1990b). Language learning strategies: what every teacher should know. Boston: Heinle \& Heinle Publishers.

[17] Oxford, Rebecca. (Ed). (1996). Learning strategies around the world. Honolulu: University of Hawaii

[18] Oxford, Rebecca and Nyikos, Martha. (1989). Variables affecting choice of language learning strategies by university students. The Modern Language Journal, 73, iii, 291-300.

[19] Oxford, Rebecca and Shearin Jill. (1994). Language learning motivation: expanding the theoretical framework. The Modern Language Journal, 78, I, 12-28.

[20] Oxford, Rebecca and Burry-Stock, Judith A. 1995). Assessing the use of language learning strategies worldwide with the ESL/EFL version of the Strategy Inventory for Language Learning (SILL). System, Vol.23 No1, 1-23.

[21] Park, Gi-Pyo. (1997). Language learning strategies and English proficiency in Korean university students. Foreign Language Annals, 30, No.2, 211-221.

[22] Politzer, Robert L. and McGroarty, Mary. (1985). An exploratory study of learning behaviors and their relationship to gains in linguistics and communicative competence. TESOL, Vol. 19, 1, 103-123.

[23] Prokop, Manfred. (1989). Learning strategies for second language users. Wales, United Kingdom: The Edwin Mellen Press.

[24] Purpura, James Enos. (1997). An analysis of the relationship between test takers' cognitive and metacognitive strategy use and second language test performance. Language Learning, 47:2, 289-325.

[25] Rubin, J. (1975). What the "Good language learner" can teach us. TESOL Quarterly, Vol.9, 41-51.

[26] Rubin, J. (1981). Study of cognitive processes in second language learning. Applied Linguistics, Vol. II, No.2, 117-131.

[27] Setiyadi, Ag. Bambang. (1999). A survey of language learning strategies of tertiary EFL students in Indonesia (unpublished thesis). Melbourne: La Trobe University.

[28] Setiyadi, Ag. Bambang. (2004). Redesigning language learning strategy classifications. TEFLIN Journal. Vol.15, No. 2.

[29] Setiyadi, Ag. Bambang.. (2009). Language learning strategies of university students in Indonesia: A new classification and its implication. In Yasir Nasanius (ed), PELBBA 19. pp. 37 - 79.

[30] Vahid Baghban, Zahra Zohoorian. (2012). The relationship between Iranian English language learners' learning styles and strategies. Journal of Language Teaching and Research, Vol. 3, No. 4, pp. 771-777.

[31] Wenden, Anita. (1985). Learner strategies. TESOL Newsletter, Vol.XIX, No.5, 4-7.

[32] Wenden, Anita. (1991a). Learner strategies for learner autonomy. New York: Prentice Hall.

[33] Wenden, Anita. (1991b). Metacognitive strategies in L2 writing: a case for task knowledge. Georgetown University Round Table on language and Linguistics, 302-321.

[34] Wenden, Anita and Rubin Juan. (1987). Learner strategies in language learning. New Jersey: Prentice Hall International. 


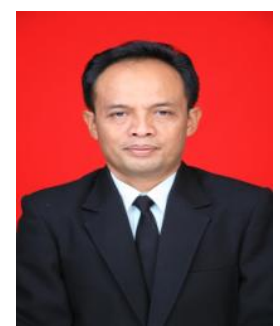

Ag. Bambang Setiyadi was born in Indonesia in 1959. He received his PhD degree in applied linguistics from $\mathrm{La}$ Trobe University, Australia in 2000. He is a professor presenting courses in language teaching methodology and research methodology at the department of English Language of Lampung University, Indonesia. He has presented and published nationally and internationally on issues related to language teaching and learning. 